\title{
Age-associated hemogram and ultrastructural leukocyte morphology in Pygocentrus nattereri (Characiformes: Serrasalmidae) from the Brazilian Pantanal
}

Correspondence:

Carlos E. Fernandes carlos.fernandes@ufms.br
Submitted December 3, 2020

Accepted February 9, 2021

by Bernardo Baldisserotto

Epub March 31, 2021

Online version ISSN 1982-0224

Print version ISSN 1679-6225

Neotrop. Ichthyol.

vol. 19, no. 1, Maringá 2021
${ }^{\oplus}$ Mayara S. Siqueira ${ }^{1,}{ }^{\oplus}$ Taynara R. F. Leão ${ }^{1},{ }^{\oplus}$ Robson A. Rodrigues ${ }^{2}$, ${ }^{\oplus}$ Karine N. N. Farias ${ }^{1},{ }^{\oplus}$ André L. N. Silva ${ }^{1},{ }^{\oplus}$ Sandriely F. Marcondes ${ }^{1}$, ${ }^{\oplus}$ Marcelo L. Veiga ${ }^{3}$, ${ }^{\oplus}$ Lilian Franco-Belussi ${ }^{1}$ and ${ }^{\oplus}$ Carlos E. Fernandes ${ }^{1}$

Pygocentrus nattereri is a carnivorous fish widely distributed in the Brazilian wetland and occupies different river strata. Based on the sexual maturity, the standard length (SL) has been used to categorize age and physiological attributes. However, hematological parameters and their relationship with age and growth features are unknow. Here, the aim was to evaluate the hematological profile and leukocyte data of juvenile and adult specimens, associating it with SL. Specimens of both sexes were weighted, and SL were measured for classify as juveniles $(\mathrm{SL} \leq 16.0 \mathrm{~cm})$ and adults $(\mathrm{SL} \geq 16.1 \mathrm{~cm})$. Blood was collected to perform the hemogram, for leukocyte quantification and ultrastructural descriptions. In general, hemogram values and leukocyte, lymphocyte, and monocyte counts were high in juveniles. Hemogram variables were negatively correlated with SL. Thrombocyte and neutrophil counts were higher in adults than in juveniles. SL was correlated with leukogram variables. Ultrastructural analysis showed that granular leukocyte count in P. nattereri was similar another fishes. PAS-positive granular leukocytes are slightly smaller than neutrophils and are characterized by dense elongated and semi-lunar shapes in the cytoplasm. Our results suggest that age-based SL may be useful for the analysis of the relationship between $P$. nattereri health status and wetland aquatic environments.

Keywords: Fish, Hematology, Leukocyte ultrastructural morphology, Standard length.

\footnotetext{
1 Laboratório de Patologia Experimental - LAPEx, Instituto de Biociências - INBIO Universidade Federal de Mato Grosso do Sul, UFMS, Av. Costa e Silva, s/n, Universitário, 79002-970 Campo Grande, MS, Brazil. (MSS) mayara schueroff@hotmail.com; (TRFL) trfleao@gmail.com; (KNNF) kanathiele@gmail.com; (ALNS) andrenascimento31@gmail.com; (SFM) sandy.marcondes@ outlook.com; (LFB) lilian.belussi@gmail.com; (CEF) carlos.fernandes@ufms.br (corresponding author).

2 Departamento de Aquicultura do Centro de Ciências Agrárias, Universidade Federal de Santa Catarina, Rodovia Admar Gonzaga, 1346, Itacorubi, 88034-001 Florianópolis, SC, Brazil. (RAR) robson.andrade@ufsc.br

3 Centro de Ciências da Saúde, Departamento de Morfologia, Universidade Federal de Santa Maria, Av. Roraima 1000, Cidade Universitária, Camobi, 97105-900 Santa Maria, RS, Brazil. (MLV) marcelolveiga@gmail.com.
} 
Pygocentrus nattereri é um peixe carnívoro amplamente distribuído no pantanal brasileiro e ocupa diferentes estratos de rios. Com base na maturidade sexual, o comprimento padrão $(\mathrm{CP})$ tem sido usado para categorizar a idade e os atributos fisiológicos. No entanto, os parâmetros hematológicos e sua relação com a idade e características de crescimento são desconhecidos. O objetivo foi avaliar o perfil hematológico e leucocitário de espécimes juvenis e adultos, associando-o ao CP. Espécimes de ambos os sexos foram pesados e os CPs foram medidos para classificação em juvenis $(\mathrm{CP} \leq 16,0 \mathrm{~cm})$ e adultos $(\mathrm{CP} \geq 16,1 \mathrm{~cm})$. Foi coletado sangue para realização do hemograma, perfil e morfologia dos leucócitos. Em geral, os valores do hemograma e as contagens de leucócitos, linfócitos e monócitos foram maiores nos jovens. A contagem de trombócitos e neutrófilos foi maior em adultos do que em jovens. A análise ultraestrutural mostrou que a contagem de leucócitos granulares em $P$. nattereri foi semelhante a outros peixes. Os leucócitos granulares PAS-positivos são menores do que os neutrófilos, sendo caracterizados por formas alongadas e semilunares densas no citoplasma. Nossos resultados sugerem que CP é útil para a análise da relação entre o estado de saúde de $P$. nattereri em ambientes aquáticos alagados.

Palavras-chave: Comprimento padrão, Hematologia, Peixe, Ultraestrutura dos leucócitos.

\section{INTRODUCTION}

The Brazilian Pantanal is a wetland region that is mainly formed by tributaries from the left margin of the Paraguay River and represents approximately $74 \%$ of the total drainage area (Alho, 2005). In the Brazilian Pantanal, the annual precipitation varies from 700 to $1,200 \mathrm{~mm}$; the wet season is between October and March, whereas the driest season is between July to September. The seasonal mean temperature is usually constant and ranges between $20^{\circ} \mathrm{C}$ in July and $27{ }^{\circ} \mathrm{C}$ in December; however, the rainfall is seasonally well defined (Krepper et al., 2006; Assine et al., 2015). Within this wetland region, there are 11 hydrographic sub-basins, including the Miranda River basin (Paranhos Filhos et al., 2017).

Pygocentrus nattereri Kner, 1858 is a member of the Serrasalmidae family, with a wide distribution in the Neotropical region. In the Brazilian Pantanal, it is known as piranha, red piranha, red-bellied piranha, yellow piranha, or true piranha (Britski et al., 2007; Froese, Pauly, 2020). Pygocentrus nattereri are highly abundant and widely distributed in different river strata. They have known feeding strategies, are easily recognizable, occupy a clear trophic position, and have a well-defined reproductive season. Hence, they are ideal for use as an ecological bioindicator in lotic or lentic environments (Chovanec et al., 2003; Burger, 2006). Their phylogeny, endoparasites, environmental life-history features, and breeding behavior have all been studied; however, their hematological profiles are unknown (Uetanabaro et al., 1993; Vicentin et al., 2013; Ferreira et al., 2014).

Hematological parameters are useful tools to detect physiological changes and have been used to assess structural and functional health in many free-range or farm fish species 
(Ranzani-Paiva et al., 2000; Tavares-Dias, Moraes, 2004). However, a central point of this theme is the wide implication of intrinsic and extrinsic factors such as species-specific features, sex, maturity stage, habitat conditions, and metabolic and physiological status on long- or short-term environment chances (Tandon, Joshi, 1976; Raizada, Singh, 1981; Almeida-Val et al., 2005). The interplay between physiological adaptations and abnormal response interpretations is strictly dependent on a systematized dataset over time. In this sense, the analysis and interpretation of different hematological parameters provide relevant information to help us understand the process of physiological adaptation (Tavares-Dias, Moraes, 2004). However, owing to the diversity of behaviors and habitats, data on hematological parameters, including a basic description and its relationship with biotic factors, of wild Pantanal ichthyofauna are limited.

On the basis of the length-weight relationship, morphometric indices provide a suitable method for speculating the body composition and growth features in fish (Bolger, Connolly, 1989; Vazzoler, 1996; Karachle, Stergiou, 2012). As the fish grow, feeding and living conditions are chances following both hematopoietic and immune system modulation (Torroba, Zapata, 2003; Ahmed et al., 2020). These changes gradually start from sexual maturity and respond to body energy reserves (Yousefian, Shirzad, 2011; Mansano et al., 2017). However, the effect of age on the linear relationship between hematological variables and standard length (SL) has been restricted to a few species. Therefore, it is reasonable to expect that there are age-related changes in the hematological values according to the body development due to subtle morphological and functional adaptations of erythropoiesis and leukopoiesis (Blaxhall, 1972; Fazio et al., 2017). This possible effect has not been investigated in P. nattereri and many other Neotropical freshwater fish.

The first registers on $P$. nattereri growth were summarized by Lowe-McConnell (1964) and later revised by Pauly (1994), who pointed out other interesting traits this species. SL was used to determine the sexual maturity and age of the specimens. Data from the Amazon basin indicate an SL of $160 \mathrm{~mm}$ in both females and males to sexual maturation at approximately 12 months of age (Lowe-McConnell, 1964; Duponchelle et al., 2007; Queiroz et al., 2010). In this study, we aimed to evaluate the association between SL and the hematological profile of juvenile and adult P. nattereri specimens and provide a morphological description of leukocytes in this species.

\section{MATERIAL AND METHODS}

Study area and sampling. This study was conducted in the Miranda River (southern Pantanal), Passo do Lontra region, Corumbá municipality, Mato Grosso do Sul State $\left(19^{\circ} 34^{\prime} 37^{\prime \prime} S, 57^{\circ} 00^{\prime} 42^{\prime \prime W}\right)$, Brazil. The experimental period consisted of dry and wet seasons according to annual environmental variations of temperature and rainfall (Alho, 2005).

Pygocentrus nattereri ( $\mathrm{n}=135$; voucher ZUFMS-PIS 05267) of both sexes were captured by a hook and line and specimens of both sexes classify as juveniles ( $\mathrm{SL} \leq 16.0$ $\mathrm{cm}$ ) and adults (SL $\geq 16.1 \mathrm{~cm}$ ) according to standard-length (Lowe-McConnell, 1964; Queiroz et al., 2010). Subsequently, the specimens were kept in a tank (1,000 L) without food, with running water at a temperature of $22-27{ }^{\circ} \mathrm{C}$ and under artificial aeration (4.8 \pm 2.0 DO mg L-1) for 12-15 h until blood sampling was conducted. 
Biometry and hematological analysis. The specimens were anesthetized with eugenol solution (50 mg-1), their weights $(\mathrm{g})$, and SLs $(\mathrm{cm})$ were recorded, and blood samples were collected. Weight and SL were used to estimate the Fulton's body condition factor $\mathrm{K}$ according to the equation $\mathrm{K}=\left(\mathrm{W} / \mathrm{L}^{3}\right) \times 100$, where $W$ is the weight (g) and $L$ is the SL (cm) of the individuals (Fulton, 1904).

Blood was collected from the caudal vein with a syringe and disposable needles slightly moistened in 3\% ethylenediaminetetraacetic acid (EDTA). The hematological parameters measured were hematocrit (\%), hemoglobin content $(\mathrm{Hb} ; \mathrm{g} / \mathrm{dL}$, cyanmethemoglobin method), and erythrocyte count $\left(\times 10^{6} \mu \mathrm{L}\right)$ using a Neubauer chamber after 1:200 dilution in 3\% formalin citrate solution. Mean corpuscular volume (MCV; fL), mean corpuscular hemoglobin ( $\mathrm{MCH} ; \mathrm{pg})$, and $\mathrm{MCH}$ concentration (MCHC; $\mathrm{g} / \mathrm{dL}$ ) were calculated from based on the erythrocyte count, hematocrit level, and hemoglobin content.

Blood extensions were stained with May-Grunwald-Giemsa-Wright stain for differential leukocyte (200 cells) and indirect counting for erythroblasts, thrombocyte, and leukocyte counts. Briefly, the total number of erythroblasts, thrombocytes, and leukocytes was estimated according to the indirect method (Ranzani-Paiva et al., 2013). The erythroblasts count was adapted as follow: total erythroblasts in blood extension $\left(\times 10^{3} \mu \mathrm{L}\right)=(\mathrm{n}$ of erythroblasts in blood extension $\times \mathrm{n}$ of erythrocytes per $\mu \mathrm{L}) / 2,000$ erythrocytes in blood extension). Total leukocytes and thrombocytes $\left(\times 10^{6} \mu \mathrm{L}\right)=(\mathrm{n}$ of leukocytes and thrombocytes in blood extension $\times \mathrm{n}$ of erythrocytes per $\mu \mathrm{L}) / 2,000$ erythrocytes in blood extension).

After blood collection, fish were euthanized in a eugenol solution $\left(450 \mathrm{mg} / \mathrm{L}^{-1}\right)$, according to Kildea et al. (2004). The spleen was weighed to estimate the splenosomatic index $($ SI \% = spleen weight $/$ body weight $\times 100)$.

Electron microscopy. For the ultrastructural study, blood samples $(n=9)$ were centrifuged at $3000 \mathrm{~g}$ for $15 \mathrm{~min}$ and the buffy coats were immediately treated with $2 \%$ glutaraldehyde solution in $0.4 \%$ phosphate buffer for $12 \mathrm{~h}$ and post-fixed in $1 \%$ osmium tetroxide diluted in the same buffer for $2 \mathrm{~h}$. Next, the buffy coats were washed in distilled water three times in 10 min baths, immersed in $0.5 \%$ uranyl acetate for approximately $2 \mathrm{~h}$, dehydrated in acetone, and incorporated in Araldite ${ }^{\circledR}$. Ultrathin sections $(50-5 \mathrm{~nm})$ were contrasted in uranyl acetate solution in 50\% alcohol for $20 \mathrm{~min}$ and lead citrate for $10 \mathrm{~min}$. The samples were analyzed using a Philips CM100 transmission electron microscope (FEI Company, Eindhoven, The Netherlands).

Statistical analysis. Hematological data were checked for normality and variance homogeneity using the Kolmogorov-Smirnov test and the Levene test, respectively. A one-way ANOVA generalized linear model was used to compared the age effect. Sex and collect data differences were not significant and were not considered. The Pearson correlation model was used to calculate the level of association between the biometric and hematological variables with SL. The association between weight (dependent) and SL (independent) was calculated by comparing the linear and quadratic regressions. SPSS $23.0\left(\mathrm{IBM}^{\circledR}\right)$ software was used to perform these analyses.

The Ethics Committee on Animal Use (CEUA/UFMS, protocol 801/2016) and 
Biodiversity Information and Authorization System (SISBIO, project $\mathrm{n}^{\circ}$ 51270-1) approved the procedures used in this study.

\section{RESULTS}

Biometric and hematological profile. All biometric variables were affected by age. Compared to juvenile specimens, adult specimens had higher SL, weight, and K-factor and lower splenosomatic index (SI). A linear correlation was observed between SL and all other variables. SI and K-factor had a negative correlation (Tab. 1). The association between weight and SL resulted in a quadratic curve fitting $\left(Y=2.5 x^{2}+47.37 x-305.32\right.$; $\left.\mathrm{R}^{2}=0.89 ; \mathrm{P}<0.001\right)$, denoting allometric growth. These results are plotted in Fig. 1.

TABLE 1 I Biometrical variables according to age in Pygocentrus nattereri and linear correlation (Pearson's model, $r$ ) with standard-length. Distinct letters represent a significant difference $(\mathrm{P}<$ 0.05); $\mathrm{SEM}=$ standard error of mean; $\mathrm{CI}=$ confidence interval; $\mathrm{r}=$ Pearson's correlation coefficient; $\mathrm{K}=$ Fulton's body condition factor; $\mathrm{SI}=$ splenosomatic index; ${ }^{* *} \mathrm{P}<0.01 ;{ }^{*} \mathrm{P}<0.05$.

\begin{tabular}{|c|c|c|c|c|c|}
\hline & \multicolumn{2}{|c|}{ Juvenile (n= 60) } & \multicolumn{3}{c|}{ Adult (n= 75) } \\
\hline Variables & Mean \pm SEM & CI (95\%) & Mean \pm SEM & CI (95\%) & r \\
\hline Standard length (cm) & $14.9 \pm 0.30^{\text {a }}$ & $14.40-15.57$ & $19.6 \pm 0.25^{\mathbf{b}}$ & $19.08-20.10$ & - \\
\hline Weight (g) & $160.9 \pm 18.03^{\text {a }}$ & $125.11-196.76$ & $363.6 \pm 15.7^{\mathbf{b}}$ & $332.47-394.71$ & $0.67^{* *}$ \\
\hline SI (\%) & $0.12 \pm 0.01^{\text {a }}$ & $0.12-0.15$ & $0.10 \pm 0.01^{\mathbf{b}}$ & $0.09-0.11$ & $-0.39^{* *}$ \\
\hline K-factor & $2.7 \pm 0.67^{\text {a }}$ & $2.59-2.86$ & $3.0 \pm 0.67^{\mathbf{b}}$ & $2.88-3.11$ & $-0.21^{*}$ \\
\hline
\end{tabular}

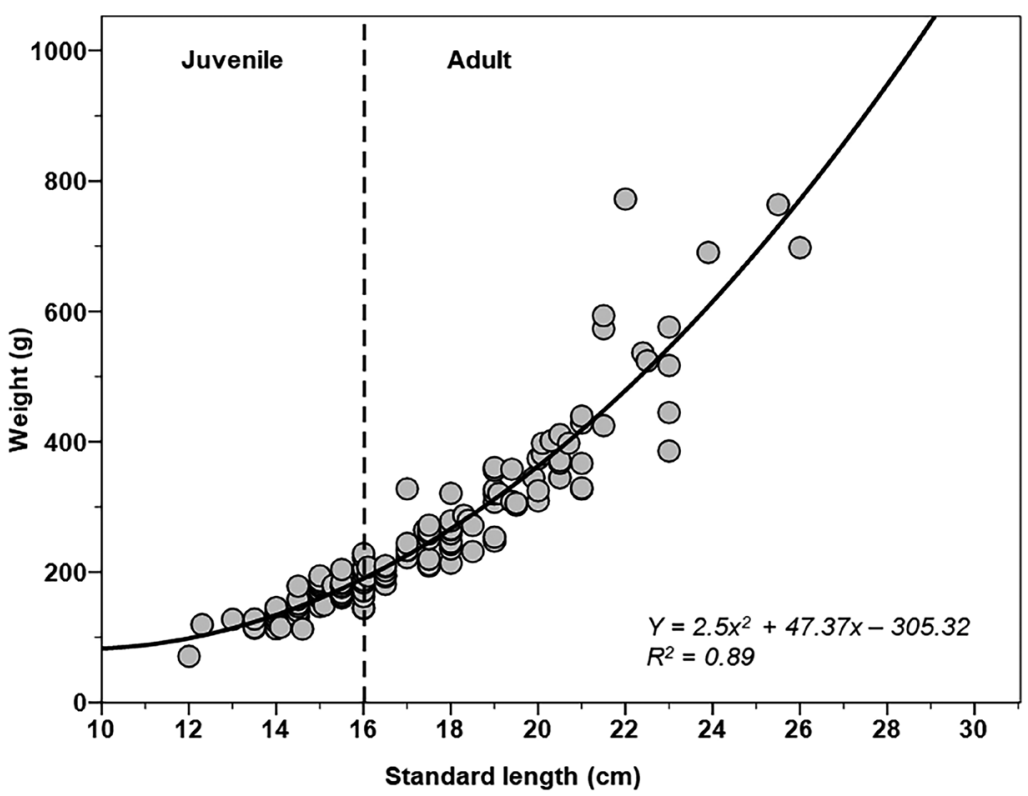

FIGURE 1 I Curve fitting between standard-length $(\mathrm{cm})$ and weight $(\mathrm{g})$ in Pygocentrus nattereri. Age cut off $(16 \mathrm{~cm})$ was applied according to Lowe-McConnell (1964). 
The Tab. 2 shows the values of the erythrogram and leukogram according to age and correlation with SL. Erythroblast count, $\mathrm{Hb}$ content, $\mathrm{MCH}$, and $\mathrm{MCHC}$ were lower in adult specimens than in juvenile specimens $(\mathrm{P}<0.05)$. In the leukogram, the thrombocyte count and percentage of neutrophils were lower in juveniles than in adults $(\mathrm{P}<0.05)$. Leukocyte count, lymphocyte, and monocyte percentage were higher in juvenile specimens than in adult specimens $(\mathrm{P}<0.05)$. However, the absolute values were higher only for lymphocytes in juveniles and not different for neutrophils and monocytes. The others types of leukocytes were not different between age in both percentage and absolute values. $\mathrm{Hb}$ content, $\mathrm{MCH}$, and $\mathrm{MCHC}$ correlated negatively with the SL, while thrombocyte count, neutrophil, and eosinophil percentage showed positive linear correlations with SL. Leukocyte count and lymphocyte percentage showed a negative correlation with SL.

TABLE 2 I Hematological variables according to age in Pygocentrus nattereri and linear correlation (Pearson's model, r) with standardlength. Distinct letters represent a significant difference $(\mathrm{P}<0.05)$; SEM = standard error of mean; $\mathrm{CI}=$ confidence interval; $\mathrm{r}=\mathrm{Pearson}$ 's correlation coefficient; RBC = red blood cell; $\mathrm{Ht}=$ hematocrit; $\mathrm{Hb}=$ hemoglobin; $\mathrm{MCV}=$ mean Corpuscular Volume; $\mathrm{MCH}=$ mean corpuscular hemoglobin; $\mathrm{MCHC}=$ mean corpuscular hemoglobin concentration; ns = not significant; ${ }^{*} \mathrm{P}<0.05,{ }^{* *} \mathrm{P}<0.01$.

\begin{tabular}{|c|c|c|c|c|c|}
\hline \multirow[b]{2}{*}{ Variables } & \multicolumn{2}{|c|}{ Juvenile $(n=60)$} & \multicolumn{2}{|c|}{ Adult $(n=75)$} & \multirow[b]{2}{*}{$r$} \\
\hline & Mean \pm SEM & (CI (95\%)) & Mean \pm SEM & (CI (95\%)) & \\
\hline \multicolumn{6}{|l|}{ Erythrogram } \\
\hline $\operatorname{RBC}\left(\mathrm{x} 10^{6} / \mu \mathrm{l}\right)$ & $1.30 \pm 0.04^{\mathrm{a}}$ & $(1.21-1.39)$ & $1.38 \pm 0.04^{\mathrm{a}}$ & $(1.30-1.47)$ & ns \\
\hline Erythroblasts count $\left(\mathrm{x} 10^{3} / \mu \mathrm{l}\right)$ & $48.50 \pm 3.87^{\mathrm{a}}$ & $(40.83-56.16)$ & $31.52 \pm 3.46^{\mathbf{b}}$ & $(24.66-38.37)$ & ns \\
\hline Ht (\%) & $34.86 \pm 0.75^{a}$ & $(33.37-36.26)$ & $36.61 \pm 0.67^{a}$ & $(35.27-37.95)$ & ns \\
\hline $\mathrm{Hb}\left(\mathrm{g} / \mathrm{dL}^{1}\right)$ & $9.02 \pm 0.23^{\mathrm{a}}$ & $(8.56-9.48)$ & $7.71 \pm 0.21^{b}$ & $(7.30-8.12)$ & $-0.29^{* *}$ \\
\hline MCV (fL) & $282.85 \pm 7.92^{a}$ & $(267.17-298.53)$ & $273.54 \pm 7.09^{a}$ & $(259.52-287.57)$ & ns \\
\hline $\mathrm{MCH}(\mathrm{pg})$ & $75.70 \pm 3.03$ a & $(69.71-81.70)$ & $58.01 \pm 2.71^{b}$ & (52.65-63.46) & $-0.25^{* *}$ \\
\hline MCHC (\%) & $26.42 \pm 0.90^{\mathrm{a}}$ & $(24.64-28.20)$ & $21.90 \pm 0.80^{b}$ & $(20.31-23.50)$ & $-0.22^{*}$ \\
\hline \multicolumn{6}{|l|}{ Leukogram } \\
\hline Thrombocytes count $\left(\mathrm{x} 10^{3} / \mu \mathrm{l}\right)$ & $47.46 \pm 4.59^{\mathrm{a}}$ & $38.37-59.55$ & $60.61 \pm 4.11^{\mathrm{b}}$ & $52.48-68.74$ & $0.21^{*}$ \\
\hline Leukocyte count $\left(\mathrm{x} 10^{3} / \mu \mathrm{l}\right)$ & $48.66 \pm 3.54^{\mathrm{a}}$ & $41.65-55.68$ & $33.65 \pm 3.17^{b}$ & $27.38-39.92$ & $-0.24^{* *}$ \\
\hline $\begin{array}{r}\text { Lymphocytes }(\%) \\
\left(\mathrm{x} 10^{3} / \mu \mathrm{l}\right)\end{array}$ & $\begin{array}{l}78.13 \pm 2.07^{\mathrm{a}} \\
38.01 \pm 10.7^{\mathrm{a}}\end{array}$ & $\begin{array}{l}74.03-82.23 \\
37.48-40.01\end{array}$ & $\begin{array}{l}68.93 \pm 1.85^{\mathbf{b}} \\
23.19 \pm 12.2^{\mathbf{b}}\end{array}$ & $\begin{array}{l}65.27-72.59 \\
21.96-24.42\end{array}$ & $-0.36^{* *}$ \\
\hline $\begin{array}{r}\text { Neutrophils (\%) } \\
\left(\mathrm{x} 10^{3} / \mu \mathrm{l}\right)\end{array}$ & $\begin{array}{l}9.74 \pm 1.56^{\mathrm{a}} \\
4.74 \pm 0.75^{\mathrm{a}}\end{array}$ & $\begin{array}{c}6.65-12.83 \\
3.23-6.24\end{array}$ & $\begin{array}{c}18.61 \pm 1.39^{\mathrm{b}} \\
6.26 \pm 0.46^{\mathrm{a}}\end{array}$ & $\begin{array}{c}15.84-21.37 \\
5.33-7.19\end{array}$ & $0.44^{* *}$ \\
\hline $\begin{array}{r}\text { Monocytes (\%) } \\
\left(\mathrm{x} 10^{3} / \mu \mathrm{l}\right)\end{array}$ & $\begin{array}{c}8.26 \pm 0.59^{\mathrm{a}} \\
2.1 \pm .017^{\mathrm{a}}\end{array}$ & $\begin{array}{l}7.11-9.41 \\
1.71-2.50\end{array}$ & $\begin{array}{c}6.66 \pm 0.52^{b} \\
1.6 \pm 0.12^{a}\end{array}$ & $\begin{array}{l}5.63-7.69 \\
1.21-1.93\end{array}$ & ns \\
\hline $\begin{array}{r}\text { Leukocyte PAS + }(\%) \\
\left(\mathrm{x} 10^{3} / \mu \mathrm{l}\right)\end{array}$ & $\begin{array}{l}0.57 \pm 0.15^{\mathrm{a}} \\
0.27 \pm 0.01^{\mathrm{a}}\end{array}$ & $\begin{array}{l}0.26-0.88 \\
0.12-0.42\end{array}$ & $\begin{array}{l}0.88 \pm 0.14^{\mathrm{a}} \\
0.29 \pm 0.04^{\mathrm{a}}\end{array}$ & $\begin{array}{l}0.60-1.16 \\
0.20-0.39\end{array}$ & ns \\
\hline $\begin{array}{r}\text { Eosinophils (\%) } \\
\left(\mathrm{x} 10^{3} / \mu \mathrm{l}\right)\end{array}$ & $\begin{array}{l}0.02 \pm 0.37^{\mathrm{a}} \\
0.01 \pm 0.18^{\mathrm{a}}\end{array}$ & $\begin{array}{l}0.04-0.09 \\
0.01-0.04\end{array}$ & $\begin{array}{l}0.06 \pm 0.03^{\mathrm{a}} \\
2.02 \pm 1.00^{\mathrm{a}}\end{array}$ & $\begin{array}{l}0.01-0.12 \\
0.00-4.04\end{array}$ & $0.19^{*}$ \\
\hline $\begin{array}{r}\text { Basophils (\%) } \\
\left(\mathrm{x} 10^{3} / \mu \mathrm{l}\right)\end{array}$ & $\begin{array}{l}0.15 \pm 0.09^{\mathrm{a}} \\
0.07 \pm 0.04^{\mathrm{a}}\end{array}$ & $\begin{array}{l}0.01-0.34 \\
0.00-0.16\end{array}$ & $\begin{array}{l}0.22 \pm 0.85^{\mathrm{a}} \\
0.07 \pm 0.28^{\mathrm{a}}\end{array}$ & $\begin{array}{l}0.05-0.38 \\
0.01-0.12\end{array}$ & ns \\
\hline $\begin{array}{r}\text { Immature leukocyte (\%) } \\
\left(\mathrm{x} 10^{3} / \mu \mathrm{l}\right)\end{array}$ & $\begin{array}{l}3.45 \pm 0.98^{\mathrm{a}} \\
1.67 \pm 0.47^{\mathrm{a}}\end{array}$ & $\begin{array}{l}1.50-5.39 \\
0.72-2.62\end{array}$ & $\begin{array}{l}4.78 \pm 0.88^{\mathrm{a}} \\
1.60 \pm 0.29^{\mathrm{a}}\end{array}$ & $\begin{array}{l}3.03-6.35 \\
1.01-2.13\end{array}$ & ns \\
\hline
\end{tabular}


Leukocytes morphology. The morphological and ultrastructural features of blood cells are reported in Figs. 2-4. Erythrocytes, thrombocytes, monocytes, and lymphocytes are shown in Fig. 1. The erythrocytes had a slightly elongated shape. The nucleus was centralized, elongated, and usually spherical, displaying condensed chromatin in the form of euchromatin (Fig. 2A). The erythrocytes ultrastructure followed the expected pattern to this cell type, with lumpy chromatin of central and peripheral distribution, nuclear membrane rich in pores, and homogeneous cytoplasm devoid of organelles. Thrombocytes had an elongated elliptical shape. The heterochromatin nuclear and sparse hyaline cytoplasm in some cells presented discrete basophilia in the region close to the plasma membrane. The nucleus showed several recesses, sometimes deep as well as several pores in the nuclear membrane. In contrast, the cytoplasm presented an abundance of small electron-dense granules and an extensive system of membranous channels, with a dense canalicular system open to the surface at various points (Fig. 2D). Monocytes were larger than erythrocytes and were irregularly shaped with cytoplasmic expansions and prominent eccentrical nuclei, predominantly composed of euchromatin with evident nucleolus chamfer. The cytoplasm was basophilic, with moderate small unspecific granules and vacuoles (Fig. 2B). Ultrastructural observations showed mitochondrial abundance, a well-developed rough endoplasmic reticulum, and a considerable number of free ribosomes and Golgi apparatus. Vacuoles of various sizes, electron-dense granules, and an abundant amount of glycogen were observed dispersed throughout the cytoplasm (Fig. 2E). Lymphocytes were spherical and smaller than $10 \mathrm{~mm}$, with a nucleus occupying most of the cell. The chromatin was usually condensed and lumpy, composed of slightly basophilic cytoplasm, and rich in projections (Fig. 2C). Their ultrastructural traits showed an irregular cell surface composed of numerous thin projections. The nuclei exhibited condensed chromatin next to the membrane, and the cytoplasm was homogeneous and scarce, with some mitochondria and few organelles (Fig. 2F).

Four types of granulocyte leukocytes, such as neutrophils, periodic acid-Schiff (PAS)positive granular leukocytes, eosinophils, and basophils, were detected under light microscopy. However, only neutrophils and PAS-positive granular leukocytes were observed on the electron microscopy transmission (Fig. 3). Neutrophils demonstrated a lumpy nucleus displaced to the cell periphery and cytoplasm with vacuoles presenting fine neutrophilic and azurophilic granulations (Fig. 3A). Using ultrastructural analysis, it was possible to identify many spherical and elongated mitochondria and a large amount of free glycogen. An extensive network of cytoplasmic synthesis structures, especially profiles of rough endoplasmic reticulum, electrodense granules, and vacuoles of size and degree of electron density were also recognized (Figs. 3B-C). PAS-positive granular leukocytes were slightly smaller than neutrophils, with an eccentric nucleus displaced close to the cell membrane of densely condensed chromatin (Fig. 3D). The cytoplasm demonstrated a slight basophilia rich in azurophilic granulations in addition to small vacuoles. The chromatin was condensed in the central and peripheral regions close to the nuclear membrane in significant electron density areas under the transmission electron microscope. Several pores were observed in the nuclear membrane. Electrodense granules of elongated and semi-lunar shapes and electrodense internal structures were identified in the cytoplasm (Figs. 3E-F).

Eosinophils were slightly smaller than neutrophils, with a twisted and irregular nucleus and loose chromatin (Fig. 4A). The cytoplasm was filled with large amounts of 


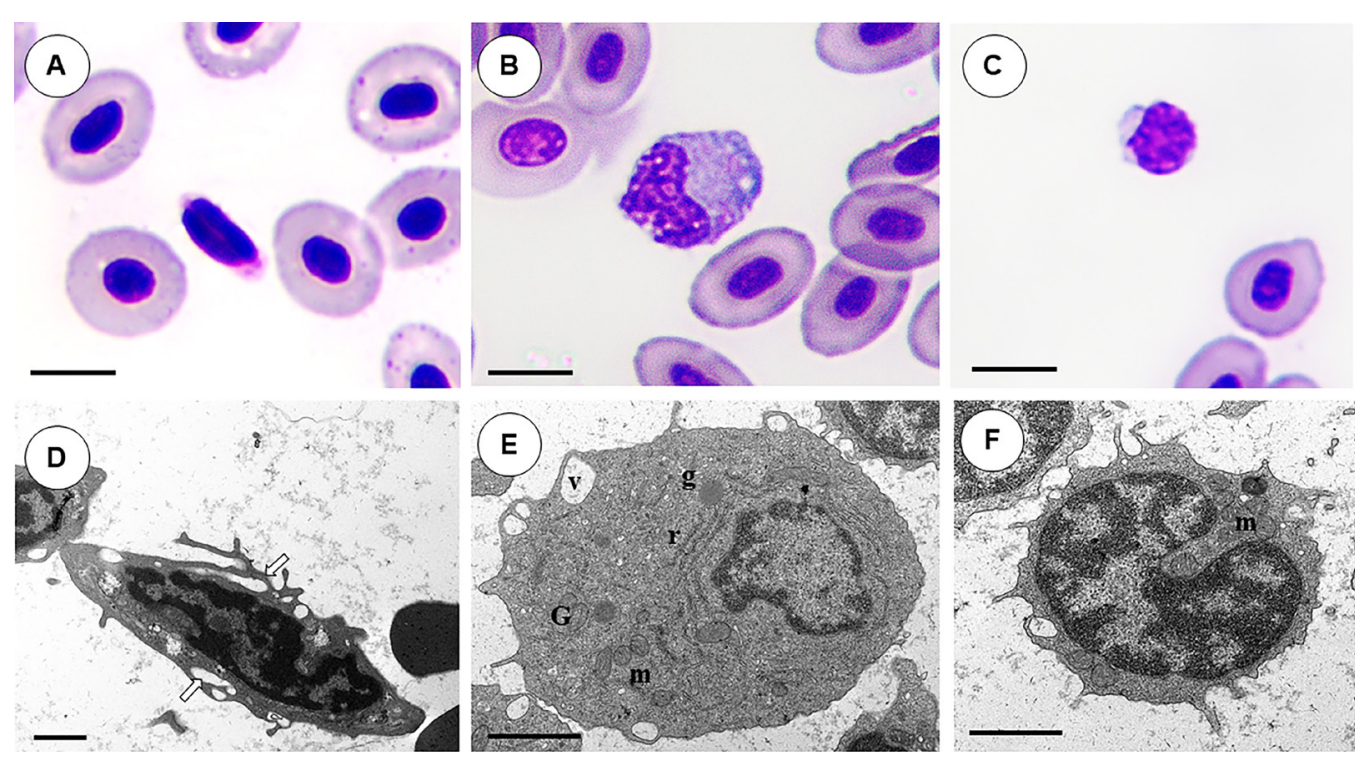

FIGURE 2 I Erythrocytes, thrombocytes and lymphocyte in Pygocentrus nattereri from Brazilian Pantanal in light (A, B, C) and transmission electronic microscopy (D, E, F). A and D. Thrombocytes of elongated shape and scarce cytoplasm rich in canalicular system (arrow). B and $\mathbf{E}$, monocytes of irregular shape, chamfered nucleus, abundant cytoplasm mitochondria (m), vacuoles (v), glycogen granules (g), Golgi apparatus (G), and free ribosomes (r) are also observed. C and F. Small lymphocyte with numerous projections, a large nucleus, and scarce cytoplasm with few mitochondria and organelles. ABC. May Grunwald-Giemsa-Wright stain. Scale bars $=\mathbf{A}-\mathbf{C}=10 \mu \mathrm{m} ; \mathbf{D}-\mathbf{F}=2 \mu \mathrm{m}$.
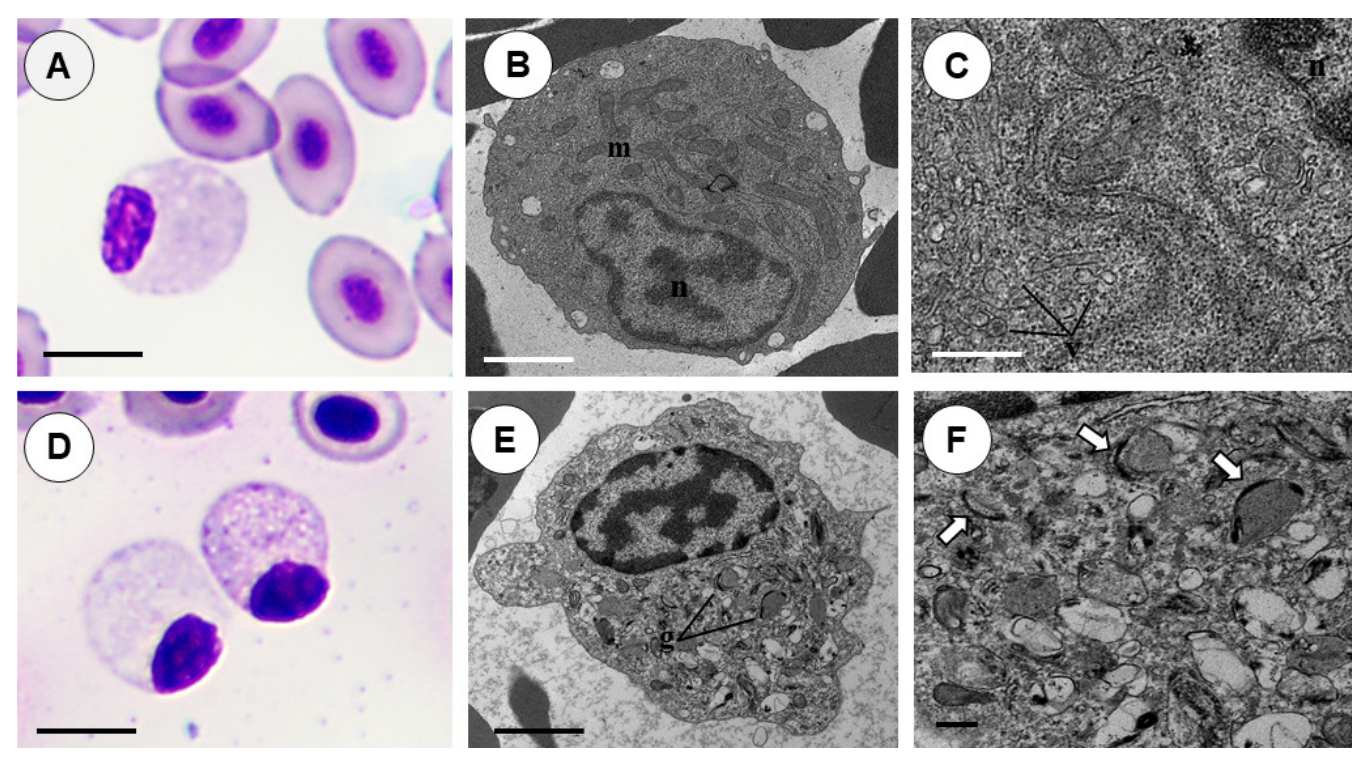

FIGURE 3 I Neutrophil and PAS-positive granular leukocytes in Pygocentrus nattereri from Brazilian Pantanal in light (A and D) and transmission electronic microscopy (B, C, E, F). A-C. Neutrophil with a lumpy nucleus and cytoplasmic vacuoles showing fine azurophilic and neutrophilic granulations. B. Mitochondria (m) and an extensive network of cell synthesis organelles are also observed; nucleus (n); C, vacuoles (v) and granules with varying size and electron density are observed. D-F. PAS-positive granular leukocyte with a displaced euchromatic nucleus; cytoplasm rich in small vacuoles and azurophilic granulation. In $\mathbf{E}$ and $\mathbf{F}$, the granules content electrolytic material is observed (g), possibly with internal electrodense areas in an elongated half-moon shape (arrows). Scale bars $=\mathbf{A}$ and $\mathbf{D}=10 \mu \mathrm{m}$ (May Grunwald-Giemsa-Wright staining), $\mathbf{B}$ and $\mathbf{E}=2 \mu \mathrm{m} ; \mathbf{C}$ and $\mathbf{F}=500 \mathrm{~nm}$. 


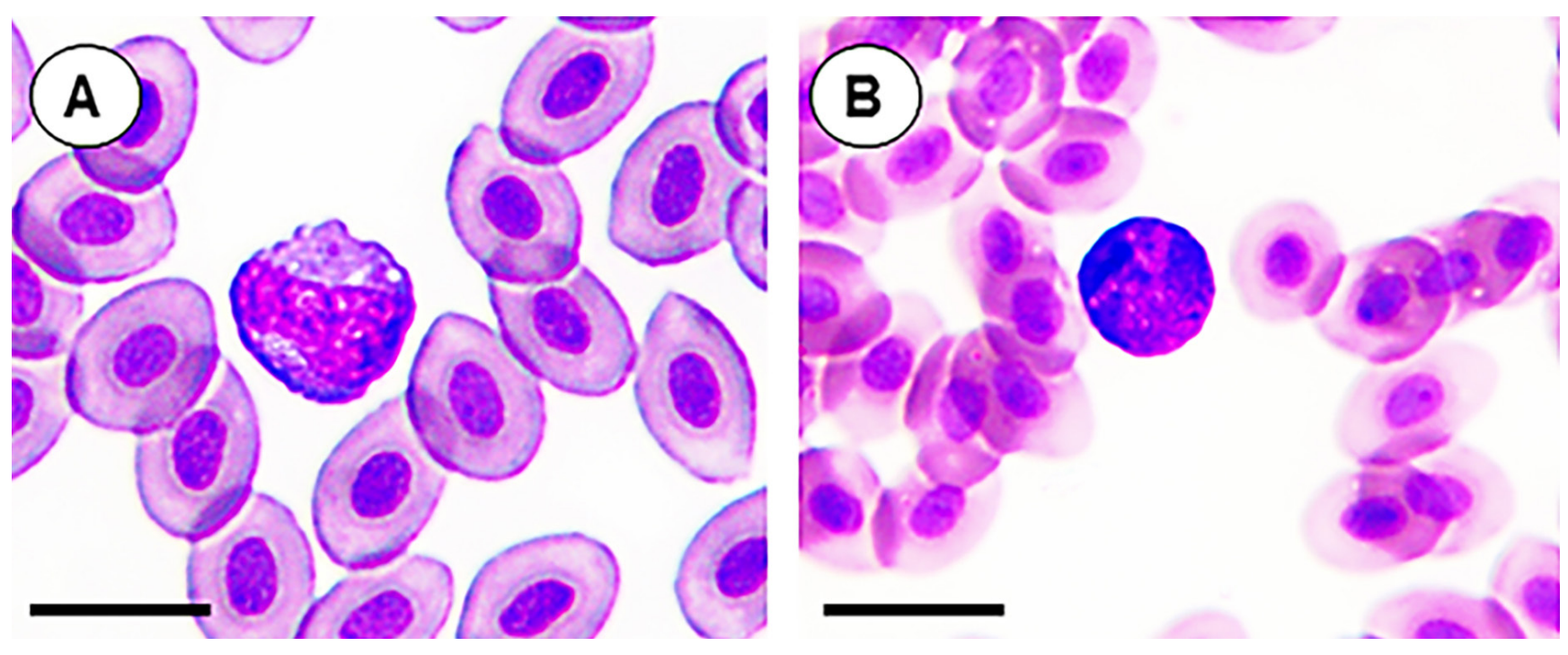

FIGURE 4 I Eosinophil and basophil in Pygocentrus nattereri from Brazilian Pantanal in May Grunwald-Giemsa-Wright staining. A. eosinophil showing irregular nucleus, loose chromatin and specific cytoplasmic granules. B. basophil surrounded by erythrocytes presenting cytoplasm filled with basophilic granulations. Scale bars $=10 \mu \mathrm{m}$.

small eosinophilic granules. Basophils were sparse, and small cells with homogeneous condensed nuclei and cytoplasm replete with coarse basophilic granulations were observed (Fig. 4B).

\section{DISCUSSION}

Aquatic environments can exhibit substantial temporal and spatial effects on the hematological features in fish. Potential factors that modulate the hematological response in fish such as sex, age, season, feeding habitat, reproductive patterns, parasites, and microbiota homeostasis interactions have been widely studied (Barber, Wright, 2005; Ahmed et al., 2020). In the present study, age and SL, assessed as a measure of body growth, affected the hematological patterns. Thus, it was possible to minimize the intra-population effect relative to the weight-length relationship, a critical factor in the variance of hematological parameters reported in fish (Tandon, Joshi, 1976; RanzaniPaiva et al., 1999; Tavares-Dias et al., 2000). However, in general, the values observed in P. nattereri agree with the range reported for the order Characiformes (Tavares-Dias, Moraes, 2004).

Splenosomatic index correlated negatively with SL, suggesting that larger and older adult specimens have a proportionally smaller or lighter spleen. This phenomenon may be owing to the allometric growth fit, which is the most significant weight gain relative to SL throughout the adult stage. Some of the erythrogram variables were lower in adult specimens than in juvenile specimens; $\mathrm{Hb}$ content, $\mathrm{MCH}$, and $\mathrm{MCHC}$ also found to be negatively correlated with SL. In general, these findings are inconsistent with those of other studies that reported an increase in the erythrogram features of aging fish (Fallah et al., 2014; Nascimento et al., 2016; Ahmed et al., 2020), although this 
relationship has not been widely studied in free-range Neotropical fish. The dynamic nature of $P$. nattereri, along with intrinsic variations of oxygen rates in response to $\mathrm{Hb}$ and its corpuscular concentration can be speculated. River-level fluctuations (decrease or increase) might result in transitory adaptation periods involving subtle modifications of both $\mathrm{Hb}$ structuration and intraerythrocytic environment (Weber, Jensen, 1988; Wells et al., 1997; Brauner, Val, 2006). In contrast, remodeling in response to energetic demand for growth, migratory behavior, food strategies, environmental effects, and higher oxygen consumption are innate characteristics in juvenile P. nattereri (Braga, 1975; Pauly, 1984; Pauly, 1994; Resende, 2003).

Leukocyte count and the percentage of circulating lymphocytes also showed negative linear correlations with SL. Although it presents recognizable species-specific variations, this tendency may be in accordance with a slight decrease in the spleen function in aging fish (Tatner, 1997; Zapata et al., 1997). In contrast, the thrombocyte count and percentage of neutrophils and eosinophils were positively correlated with SL. Both types of cells categories originate from erythroid/myeloid progenitor cells and involve a classical fish innate response (Ferdous, Scott, 2015; Havixbeck, Barreda, 2015). The thrombocyte count was similar to the lymphocyte count in juvenile specimens, but it was almost double than the lymphocyte count in adults. In addition to hemostatic function, these cells are critical for recognizing and phagocytizing anomalous structures in conjunction with neutrophils (Stosik et al., 2002; Nagasawa et al., 2014).

To the best of our knowledge, this is the first descriptive study of blood morphology in P. nattereri. Peripheral cells in P. nattereri are similar to those observed in the vast majority of fish species; however, given many species, particularities can be observed, making the diagnosis complex. Erythrocytes have similar morphology and ultrastructure to those observed in almost all fish (Veiga et al., 2000, 2002; Santos et al., 2011; Kelly, Gibson-Kueh, 2015; Chen et al., 2019), suggesting a high degree of conservation and evolutionary success. Thrombocytes, in particular, emphasize the abundance of cytoplasmic organelles associated with phagocytosis, storage, and secretion of immune control molecules (Veiga et al., 2000, 2002; Tavares-Dias, Moraes, 2007; Santos et al., 2011; Kelly, Gibson-Kueh, 2015; Chen et al., 2019). Monocytes are similar to those reported in Salminus maxillosus (currently Salminus brasiliensis (Cuvier, 1816)) and Centropomus parallelus Poey, 1860 (Veiga et al., 2000, 2002; Santos et al., 2011); however, they are larger with more basophilic cytoplasm and preeminent in organelles than those described in other fish species. Similarly, lymphocytes show remarkable homogeneity of characteristics concerning other species differing from the large or small classification used in some species (Veiga et al., 2000, 2002; Dikic et al., 2013; Kelly, Gibson-Kueh, 2015).

One difficulty in hematological research and clinical practice for fish is that there is no consensus on the classification and nomenclature of granulocytes, given the wide range of morphology among species and the absence of any cell type or the occurrence of the fourth type of granulocyte. For instance, neutrophils show morphology and ultrastructure similar to several other species and granulocyte type I Salminus maxillosus (Veiga et al., 2002); however, the latter has fewer mitochondria and more granules, which also have greater size and electron density. Smaller neutrophils, with a more stable nucleus, less cytoplasmic basophilia, and poor organelles into the cytoplasm, have been observed in three different species of Characids (Chen et al., 2019). Similar cells 
to neutrophils observed by us were called granulocyte non-eosinophilic in Glaucostegus cemiculus (Geoffroy St. Hilaire, 1817) (Sofia Carmezin, Marcos, 2020).

The morphology of PAS-positive leukocytes is similar to that described in elasmobranchs and several species of Siluriforms and Characids (Veiga et al., 2002; Kelly, Gibson-Kueh, 2015; Sofia Carmezin, Marcos, 2020). The presence of crystalloid in a semilunar shape characterizes the type II granulocyte or neutrophil in Salminus maxillosus (Veiga et al., 2002) and is similar to the so-called neutrophil or type I granulocyte in other species (Tavares-Dias, Moraes, 2007; Flerova, Balabanova, 2013). Eosinophils with contorted nuclei and fine and abundant eosinophilic granulation are similar in most species with regard to the shape and abundance of the granules. Although basophils are rare cells in peripheral blood, they have a certain homogeneity with respect to other species (Tavares-Dias, Moraes, 2007; Kelly, Gibson-Kueh, 2015).

Considering the limited information on the hematology of P. nattereri and the quantitative and morphological features, the findings of the present study can be used as preliminary references for future studies. As a measure to estimate the age stages, the correlation between SL and hematological profile dynamics can be used in future studies to expand the knowledge on the relationship of this species with the wetland aquatic environment.

\section{ACKNOWLEDGMENTS}

We thank the Animal Biology Post-graduate Program by the logistic support and the staff team through special assistance in the Research Base of Pantanal/UFMS. We also wish to thank Fundação de Apoio ao Desenvolvimento do Ensino, Ciência e Tecnologia de Mato Grosso do Sul (FUNDECT/MS, process $n^{\circ}$ 59/300.591/2016) for financially supporting this study.

\section{REFERENCES}

- Ahmed I, Reshi QM, Fazio F. The influence of the endogenous and exogenous factors on hematological parameters in different fish species: a review. Aquac Int. 2020; 28(1):869-99. https://doi.org/10.1007/s10499019-00501-3

- Alho CJR. The Pantanal. The world's largest wetlands. In: Lauchlan H, Fraser LH, Keddy PA, editors. Ecology and conservation. Cambridge University Press; 2005. p.203-71.

- Almeida-Val VMF, Chippari-Gomes AR, Lopes NP. Metabolic and physiological adjustments to low oxygen and high temperature in fishes of the Amazon. In: Val AL, Almeida-Val VMF, Randall D, editors The physiology of tropical fishes. London: Elsevier; 2005. p.443-500.
- Assine ML, Macedo HA, Stevaux JC, Bergier I, Padovani CR, Silva A. Avulsive rivers in the hydrology of the Pantanal wetland. In: Barceló D, Kostianoy AG, editors. The handbook of environmental chemistry. Dynamics of the Pantanal wetland in South America. Springer; 2015. p.82-110.

- Barber I, Wright HA. Effects of parasites on fish behaviour: interactions with host physiology. Fish Physiol. 2005; 24(1):109-49. https://doi.org/10.1016/S15465098(05)24004-9

- Blaxhall PC. The haematological assessment of the health of freshwater fish: a review of selected literature. J Fish Biol. 1972; 4(4):593-604. https://doi. org/10.1111/j.1095-8649.1972.tb05704.x 
- Bolger T, Connolly PL. The selection of suitable indices for the measurement and analysis of fish condition. J Fish Biol. 1989; 34(2):171-82. https://doi. org/10.1111/j.1095-8649.1989.tb03300.x

- Braga RA. Ecologia e etologia de piranhas no nordeste do Brasil (Pisces, Serrasalmus Lacépede, 1803). Fortaleza: DNOCS; 1975.

- Brauner CJ, Val AL. Oxygen Transfer. In: Val AL, Almeida-Val VMF, Randall D, editors. The physiology of tropical fishes. London: Elsevier; 2006. p.277-306.

- Britski HA, Silimon KZS, Lopes BS. Peixes do Pantanal: manual de identificação. Embrapa; 2007.

- Burger J. Bioindicators: Types, development, and use in ecological assessment and research bioindicators in ecological assessment and research. Environ Bio. 2006; 1(1):22-39. https://doi. org/10.1080/15555270590966483

- Chen H, Yuan G, Su J, Liu

$\mathbf{X}$. Hematological analysis of Ctenopharyngodon idella, Megalobrama amblycephala and Pelteobagrus fulvidraco: Morphology, ultrastructure, cytochemistry and quantification of peripheral blood cells. Fish Shellfish Immun. 2019; 90(7):376-84. https://doi.org/10.1016/j. fsi.2019.04.044

- Chovanec A, Hofer R, Schiemer F. Fish as bioindicators. In: Markert BA, Breure AM, Zechmeister HG, editors. Bioindicators and Biomonitors. London: Elsevier; 2003. p.639-76.

- Đikić D, Lisičić D, Matić-Skoko S, Tutman P, Skaramuca D, Franić Z, Skaramuca B. Comparative hematology of wild Anguilliformes (Muraena helena, L. 1758, Conger conger, L. 1758 and Anguilla anguilla L. 1758). Animal Biol. 2013; 63(1):77-92. https://doi. org/10.1163/15707563-00002395

- Duponchelle F, Lino F, Hubert N, Panfili J, Renno JF, Baras E, Torrico JP, Dugue R, Nunez J. Environment related life history trait variations of the red bellied piranha Pygocentrus nattereri in two river basins of the Bolivian Amazon. J Fish Biol. 2007; 71(4):1113-34. https://doi.org/10.1111/ j.1095-8649.2007.01583.x

- Fallah FJ, Khara H, Roohi JD, Boorani MS. Hematological parameters of pike Esox lucius in relation to different ages and seasons. Comp Clin Path. 2014; 23(4):949 53. https://doi.org/10.1007/s00580-013-17193
- Fazio F, Saoca C, Vazzana I, Piccione G. Influence of body size on blood hemogram in rainbow trout Oncorhynchus mykiss (Walbaum, 1792). Vet Med Open J. 2017; 2(3):91-94. https://doi.org/10.17140/VMOJ2-121

- Ferdous F, Scott TR. A comparative examination of thrombocyte / platelet immunity. Immun Letters. 2015; 163(1):32-39. https://doi.org/10.1016/j. imlet.2014.11.010

- Ferreira FS, Vicentin W, Costa FES, Súarez YR. Trophic ecology of two piranha species, Pygocentrus nattereri and Serrasalmus marginatus (Characiformes, Characidae), in the floodplain of the Negro River, Pantanal. Acta Limnol Bras. 2014. 26(4):381-91. https://doi.org/10.1590/S2179975X2014000400006

- Flerova EA, Balanova LV. Ultrastructure of granulocytes of teleost fish (Salmoniformes, Cypriniformes, Perciformes). J Evol Biochem Physiol. 2013; 49(2):223-33. https://doi.org/10.1134/ S0022093013020126

- Froese R, Pauly D. FishBase 2020, version (november, 2020). World Wide Web electronic publication. Available from: http://www. fishbase.org

- Fulton TW. The rate of growth of fishes. 22nd Annual Report of the Fishery Board of Scotland. 1904; 3:141-241.

- Havixbeck JJ, Barreda DR. Neutrophil development, migration, and function in teleost fish. Biology. 2015; 4(4):715-34. https://doi.org/10.3390/biology4040715

- Karachle PK, Stergiou KI. Morphometrics and allometry in fishes. Morphometrics. 2012; 65-86. https://doi.org/10.5772/34529

- Kelly E, Gibson-Kueh S. The haematology of six species of native catfish from northern Australia. Aust J Zool. 2015; 63(5):293-99. https://doi.org/10.1071/ ZO15040

- Kildea MA, Allan GL, Kearney RE. Accumulation and clearance of the anesthetics clove oil and AQUI341S ${ }^{\mathrm{TM}}$ from the edible tissue of silver perch (Bidyanus bidyanus). Aquaculture. 2004; 232(1-4):265-77. https://doi.org/10.1016/ S0044-8486(03)00483-6

- Krepper CM, García NO, Jones PD. Paraguay river basin response to seasonal rainfall. Int J Climatol. 2006; 26(9):1267-78. https://doi.org/10.1002/joc.1313 
- Lowe-McConnell RH. The fishes of the Rupununi Savana distinct of British Guyana, South America. Zool J Linn Soc. 1964; 45:103-44.

- Mansano CFM, Macente BI, Khan KU, do Nascimento TMT, da Silva EP, Sakomura N K, Fernandes JBK. Morphometric growth characteristics and body composition of fish and amphibians. New insights into morphometry studies. London: InTech, 2017; 7-28.

- Nagasawa T, Nakayasu C, Rieger AM, Barreda DR, Somamoto T, Nakao M. Phagocytosis by thrombocytes is a conserved innate immune mechanism in lower vertebrates. Front Immunol. 2014; (5)445:7-28. https://doi.org/10.3389/ fimmu.2014.00445

- Nascimento NF, Nakaghi LSO, Hilbig CC, Ventura AS, de Azevedo ACB, Dean AF, Bombardelli RA. Influences of sex and age on the hematological profile of the Jundiá (Silver Catfish) Rhamdia quelen. J Aquat Anim Health. 2016; 28(3):161-65. https:// doi.org/10.1080/08997659.2016.1173603

- Paranhos Filho AC, Mioto CL, Machado R, Gonçalves FV, Ribeiro Vo, Grigio AM, Silva NM. Controle estrutural da hidrografia do pantanal, Brasil. Anuário IGEO. 2017; 40(1):156-70. https://doi. org/10.11137/2017_1_156_170

- Pauly D. A mechanism for the juvenileto-adult transition in fishes. ICES J Marine Sci.1984; 41(3):280-84. https://doi. org/10.1093/icesjms/41.3.280

- Pauly D. Quantitative analysis of published data on the growth, metabolism, food consumption, and related features of the red-bellied piranha, Serrasalmus nattereri (Characidae). Environ Biol Fish. 1994; 41:423-37. https://doi.org/10.1007/ BF02197858

- Queiroz HL, Sobanski MB, Magurran AE. Reproductive strategies of Red-bellied Piranha (Pygocentrus nattereri Kner, 1858) in the white waters of the Mamirauá flooded forest, central Brazilian Amazon. Environ Biol Fishes. 2010; 89(1):11-19. https://doi.org/10.1007/s10641-010-9658-1

- Raizada MN, Singh CP. Seasonal variations in the differential leucocyte counts (DLC) of Cirrhinusmrigala (Ham). The Indian journal of zootomy. 1981. 22(3):147-50.

- Ranzani-Paiva MJT, Pádua SBP, TavaresDias M, Egami MI. Métodos para análise hematológica em peixes. Maringá: EDUEM; 2013
- Ranzani-Paiva MJT, Salles AF, Eiras JC, Eiras AC, Ishikawa CM, Alexandrino AC. Análises hematológicas de curimbatá (Prochilodus scrofa), pacu (Piaractus mesopotamicus) e tambaqui (Colossoma macropomum) das estações de piscicultura do Instituto de Pesca, Estado de São Paulo. B. Inst. Pesca, São Paulo. 1999; 25:77-83.

- Ranzani-Paiva MJT, Souza ATS, Pavanelli GC, Takemoto RM, Eiras AC. Hematological evaluation in commercial fish species in the floodplain of the upper Paraná River, Brazil. Acta Scientiarum. 2000; 22(2):507-13. Available from: https://www.researchgate.net/ publication/284236040_Hematological_ evaluation_in_commercial_fish_species_ from_the_floodplain_of_the_upper_ Parana_River_Brazil

- Resende EK. Migratory fishes of the Paraguay-Paraná basin, excluding the upper Paraná basin. Migratory Fishes of South America: biology, fisheries and conservation status. Victory: Canada, World Fisheries Trust; 2003.

- Santos AA, Gutierre RC, Antoniazzi MM, Ranzani-Paiva MJT, Silva MRR, Oshima CTF, Egami MI. Morphocytochemical, immunohistochemical and ultrastructural characterization of the head kidney of fat snook Centropomus parallelus. J Fish Biol. 2011; 79(7):1685-707. https://doi. org/10.1111/j.1095-8649.2011.02718.x

- Sofia Carmezin H, Marcos R. There is plenty more fish nomenclature in the sea: The elasmobranch granulocytes. Vet Clin Path. 2020; 49(2):196-97. https://doi. org/10.1111/vcp.12875

- Stosik M, Deptuia W, Travnicek M, Baldy-Chudzik K. Phagocytic and bactericidal activity of blood thrombocytes in carps (Cyprinus carpio). Vet Med. 2002; 47(1):21-25.

- Tandon RS, Joshi BD. Total red and white blood cell count of 33 species of fresh water teleosts. Z Tierphysiol Tierernaehrg Futtermittelkd. 1976; 37(1-6):293-97. https://doi.org/10.1111/j.1439-0396.1976. tb00069.x

- Tatner ME. Natural changes in the immune system of fish. In: Iwama G, Nakanishi T, editors. The Fish Immune System. London: Academic Press; 1997. p.255-87.

- Tavares-Dias M, de Moraes FR. Hematologia de peixes teleósteos. Ribeirão Preto; 2004. 
- Tavaraes-Dias M, de Moraes FR. Leukocyte and thrombocyte reference values for channel catfish (Ictalurus punctatus Raf), with an assessment of morphologic, cytochemical, and ultrastructural features. Vet Clin Path. 2007; 36(1):49-54. https://doi.org/10.1111/ j.1939-165X.2007.tb00181.x

- Tavares-Dias M, Schalch SHC, Martins ML, Onaka EM, Moraes FR. Haematological characteristics of Brazilian teleosts. III. Parameters of the hybrid tambacu (Piaractus mesopotamicus Holmberg, 1887 x Colossoma macropomum Cuvier, 1818) (Osteichthyes: Characidae). Rev Bras Zool. 2000; 17(4):899-926. https:// doi.org/10.1590/S0101-81752000000400002

- Torroba M, Zapata AG. Aging of the vertebrate immune system. Microsc Res Techniq. 2003; 62(6):477-81. https://doi. org/10.1002/jemt.10409

- Uetanabaro M, Wang T, Abe AO. Breeding behaviour of the red-bellied piranha, Pygocentrus nattereri, in nature. Environ Biol Fishes. 1993; 38:369-71. https://doi.org/10.1007/BF00007529

- Vazzoler AEAM. Biologia da reprodução de peixes teleósteos: teoria e prática. Maringá: Eduem, 1996.

- Veiga ML, Egami MI, Ranzani-Paiva MJT, Rodrigues EL. Aspectos morfológicos y citoquímicos de las células sanguíneas de Salminus maxillosus Valenciennes, 1840 (Characiformes, Characidae). Rev Chil Anat. 2000; 18(2):245-50. http://dx.doi. org/10.4067/S0716-98682000000200005
- Veiga ML, Egami MI, Ranzani-Paiva MJ, Rodrigues EL. Morphological and ultrastructural study of the thrombocytes and leukocyte granulocytes of Salminus maxillosus (Characiformes, Characidae). J Submic Cytol Pathol. 2002; 34(4):397-402.

- Vicentin W, Costa FES, Súarez YR. Population ecology of Red-bellied Piranha Pygocentrus nattereri Kner, 1858 (Characidae: Serrasalminae) in the Negro River, Pantanal, Brazil. Environ Biol Fish. 2013; 96:57-66. http://doi.org/10.1007/ s10641-012-0022-5

- Yousefian M, Shirzad E. The review of the effect of growth hormone on immune system, metabolism and osmoregulation of fish. Aust J Basic Appl Sci. 2011; 5(5):46775.

- Weber RE, Jensen FB. Functional adaptations in hemoglobins from ectothermic vertebrates. Ann Rev Physiol. 1988; 50:161-79. http://doi.org/10.1146/ annurev.ph.50.030188.001113

- Wells RMG, Baldwin J, Seymour RS, Weber RE. Blood oxygen transport and hemoglobin function in three tropical fish species from northern Australian freshwater billabongs. Fish Physiol Biochem. 1997; 16:247-58. https://doi. org/10.1023/A:1007734001284

- Zapata A, Chiba A, Varas A. Cells and tissues of the immune system of fish. In: Iwama G, Nakanishi T, editors. The fish immune system: organism, pathogen and environment. Academic Press; 1997. p.1-62.

\section{AUTHOR'S CONTRIBUTION œ}

Mayara S. Siqueira: Conceptualization, Formal analysis, Investigation, Methodology, Writing-original draft.

Taynara R. F. Leão: Investigation, Methodology.

Robson A. Rodrigues: Conceptualization, Investigation, Methodology, Writing-original draft.

Karine N. N. Farias: Investigation, Methodology.

André L. N. Silva: Investigation, Methodology.

Sandriely F. Marcondes: Investigation, Methodology.

Marcelo L. Veiga: Formal analysis, Writing-original draft, Writing-review and editing.

Lilian Franco-Belussi: Formal analysis, Writing-original draft, Writing-review and editing.

Carlos E. Fernandes: Conceptualization, Formal analysis, Investigation, Methodology, Resources,

Writing-original draft, Writing-review and editing.

\section{ETHICAL STATEMENT}

The Ethics Committee on Animal Use (CEUA/UFMS, protocol 801/2016) and Biodiversity Information and Authorization System (SISBIO, project no 51270-1) approved the procedures used in this study. 


\section{Neotropical |chthyology}

\section{open Daccess $_{\text {a }}$}

\section{(c) (1)}

This is an open access article under the terms of the Creative Commons Attribution License, which permits use, distribution and reproduction in any medium

cheris

Distributed under

Creative Commons CC-BY 4.0

๑) 2021 The Authors.

Diversity and Distributions Published by SBI

\section{Official Journal of the}

3 Sociedade Brasileira de Ictiologia SBI

\section{COMPETING INTERESTS}

The authors declare no competing interests.

HOW TO CITE THIS ARTICLE

- Siqueira MS, Leão TRF, Rodrigues RA, Farias KNN, Silva ALN, Marcondes SF, Veiga ML, Franco-Belussi L, Fernandes CE. Age-associated hemogram and ultrastructural leukocyte morphology in Pygocentrus nattereri (Characiformes: Serrasalmidae) from the Brazilian

Pantanal. Neotrop Ichthyol. 2021; 19(1):e200136. https://doi.org/10.1590/1982-0224-2020-0136 